Biotechnology Research

http:/www.journals.zu.edu.eg/journalDisplay.aspx?Journalld=1\&queryType=Master

\title{
SCREENING OF POTENTIAL PROBIOTIC LACTIC ACID BACTERIA FROM DIFFERENT SOURCES BY In vitro TESTS
}

\author{
Maha M. Nader*, E.M. Gewaily, V.S. Bedrous and G.M. Mohamed \\ Agric. Microbiol. Dept., Fac. Agric., Zagazig Univ., Egypt
}

Received: 08/11/2017 ; Accepted: 26/11/2017

\begin{abstract}
A total of 87 isolates of lactic acid bacteria (LAB) were isolated anaerobically from different food sources (yoghurt; Domiati cheese; fresh and fermented milk; mixed pickles and green olives), as well as human breast milk and infant stools. Only ten isolates showed high tolerance to $\mathrm{pH}$ 3.0 for three hours and therefore they were chosen for other studies. The selected isolates were identified based on physiological, biochemical and MALDI- TOF mass spectrometry identification. The most frequently observed genus was Lactobacillus ( 8 isolates) and one isolate seemed to be Enterococcus faecium and another isolate showed that it is Bifidobacterium bifidium. All of the tested species with a score value between 2.000 to 2.484 (100\%) were correctly identified by MALDI -TOFMS to the genus and species levels. The majority of LAB species were tolerant to $0.3 \%$ bile salts for up to $4 \mathrm{hrs}$ but $L$. fermentum was the most tolerant. Four species exhibited partial bile salt hydrolase activity. All of the species survived in $1 \mathrm{mg} / \mathrm{ml}$ pancreatin for $4 \mathrm{hrs}$. However, two of them showed $1 / 10$ decrease in their numbers. Eight species were non haemolytic. Most of the tested species were resistant to penicillin $(10 \mu \mathrm{g})$, ciprofloxacin $(5 \mu \mathrm{g})$, gentamycin $(10 \mu \mathrm{g})$ and streptomycin $(10 \mu \mathrm{g})$. However other species showed variable resistance against the ten tested antibiotics according to NCCLS. The cell free supernatant of L. acidophilus (IS9) showed the highest antimicrobial property against all the indicator pathogens tested specially Staphylococcus aureus and Klebsiella pneumoniae. Therefore, these 10 species were found, in vitro, to possess desirable properties in order to use as probiotic for human consumption.
\end{abstract}

Key words: Lactic acid bacteria, probiotic, antimicrobial and antibiotic resistance.

\section{INTRODUCTION}

Probiotics are live microorganisms defined according to FAO/WHO (2002) as: "Live microorganisms whose administration in adequate amount to the body is able to confer a health beneficial effect on the host". The term probiotic, literally meaning "for life", was first addressed by Lilly and Stillwell (1965). Nowadays, the term refers to viable, nonpathogenic microorganisms (bacteria or fungi) that, when ingested, are able to reach the intestines in sufficient numbers to confer health benefits to the host (De Vrese and Schrezenmeir, 2008). Commonly used bacterial probiotics include various species of
Lactobacillus, Bifidobacterium and Streptococcus, as well as Lactococcus lactis and some Enterococcus species. Currently, the only probiotic yeast used is the nonpathogenic Saccharomyces boulardii (Morrow et al., 2012). In order for a probiotic specie to exert its beneficial effect on the host, it has to be able to survive passage through the host's digestive tract. Researchers have mainly focused on species sensitivity towards low $\mathrm{pH}$, proteolytic enzymes and bile salts (Conway et al., 1987; Charteris et al., 1998a; Du Toit et al., 1998; Jacobsen et al., 1999). Another relevant property is the ability of probiotic bacteria to assimilate cholesterol (Du Toit et al., 1998). This has been linked to the bile salt

\footnotetext{
* Corresponding author: Tel. : +201010055242

E-mail address: mahanaderdiab@gmail.com
} 
deconjugation activity of some species because of the enzyme bile salt hydrolase (BSH).

Most of the studies published about physiological properties of species intended to be used as probiotics are performed on species from human or animal internal cavities, considering that species of these origins would be better adapted and colonize the human/ animal gastrointestinal tract (Johansson et al., 1993; Parasad et al., 1999; Ouwehand et al., 2002; Ruiz- Moyano et al., 2009; Zacarías et al., 2011; Xanthopoulos et al., 2012). On the other hand, research on probiotic functions of lactic acid bacteria isolated from foods like dairy products has started to increase (Maragkoudakis et al., 2006; Bao et al., 2010; Espeche et al., 2012; Monteagudo-Mera et al., 2012), dry sausages (Papamanoli et al., 2003; De Vuyst et al., 2008), foods of plant origin (Husmaini et al., 2011) and fruits, cereals, meat or fish (Rivera-Espinoza and Gallardo-Navarro, 2010). Traditional fermented foods are a plentiful source of microorganisms and some of them show probiotic characteristics, although the research of these matrices as raw material for probiotic microorganisms is still scarce compared with their dairy counter part (RiveraEspinoza and Gallardo- Navarro, 2010).

Several mechanisms by which probiotics mediate their health benefits on the host have been suggested, and can be divided into three categories; certain probiotics have antimicrobial activity and can exclude or inhibit pathogens; probiotic bacteria can enhance the intestinal epithelial barrier; and probiotic bacteria are believed to modulate the host immune response (Marco et al., 2006; Lebeer et al., 2008). Probiotics can produce a wide range of antimicrobial metabolites, i.e. organic acids, diacetyl, acetoin, hydrogen peroxide and bacteriocins. These antimicrobial activities can contribute in the microbiological safety by controlling the growth of other microorganisms, and inhibition of pathogenic bacteria (Hobbs, 2000; Ouweh and Vest, 2004). The reported health benefits of probiotics include: boosting of the immune system, inhibition of the growth of pathogenic microorganisms, prevention of diarrhea from various causes, prevention of cancer, reduction of the risk of inflammatory bowel movements, improvement of digestion of proteins and fats, synthesis of vitamins, and detoxification and protection from toxins Sonomoto and Yokota (2011).

Probiotics could maintain gut microbiota during or after antibiotic treatment through receptor competition, competition for nutrients, epithelial inhibition, and mucosal adherence of pathogens (Clemente et al., 2012). Many of probiotics, which are lactic acid bacteria and anaerobic bifidobacteria, have been reported to be useful in the treatment of disturbed gut microbiota and diarrheal diseases. Thus, probiotic-based approaches that restore gut homeostasis are viewed as promising therapies for bacteria caused disease.

The aim of this study was to isolate and identify novel probiotic species originating from different sources and to evaluate their probiotic potential and safety in order to be used as health-promoting, functional foods.

\section{MATERIALS AND METHODS}

\section{Isolation of Lactic Acid Bacteria from Different Sources}

Lactic acid bacteria (LAB) were isolated from yoghurt, Domiati cheese, fresh and fermented milk, mixed pickles and green olives. Also human samples represented in human breast milk and infant stools were collected from two healthy mother volunteers and their infants, respectively. The samples were collected using sterile bottles and stored in an ice box until delivering to the laboratory of Agric. Microbiology Department, Fac.Agric, Zagazig University for analysis. One gram/milliliter of each sample was diluted in $0.9 \%$ sterile saline solution to a final volume of $10 \mathrm{ml}$ and $0.1 \mathrm{ml}$ of each dilution was plated onto selective MRSmedium (DeMan, Rogosa-Sharpe, Oxoid, CM 361). MRS medium was supplemented with $0.05 \%$ cysteine hydrochloride to improve the specificity of this medium for isolation of Lactobacillus acidophilus (Diba et al., 2013) and bifidobacteria (Parasad et al., 1999). The $\mathrm{pH}$ of the media was adjusted to 6.5 and 5.2, respectively using a digital electrode $\mathrm{pH}$ meter. Plates were incubated at $37 \pm 2^{\circ} \mathrm{C}$ anaerobically in jars with AnaeroGen sacks (Oxoid,UK) for 48 hrs. After incubation different colonies were 
randomly collected from each sample, the selected colonies were purified by streak plate technique. The purified bacterial isolates were stored in MRS broth at $4^{\circ} \mathrm{C}$ for further studies. As probiotic bacteria should pass through a highly acidic stomach in order to reach the intestine and accordingly creating proper conditions for residence (Maragkoudakis et al., 2006; Argyri et al., 2013). Therefore, the first step in screening the probiotic isolates is selecting those which showed acid resistance.

\section{Preliminary Identification of Lactic Acid Bacteria}

Morphological and biochemical characters were used to identify the most acid resistant bacterial isolates according to Logan and De vos (2009), the following tests were performed: cell morphology, Gram reaction, catalase test, ammonia production, growth at $10^{\circ} \mathrm{C}$ for 5 days and $45^{\circ} \mathrm{C}$ for $48 \mathrm{hr}$., in MRS broth, salt tolerance $(4 \%, 6.5 \% \mathrm{NaCl}$ in MRS). Sugar fermentation tests were applied using D-trehalose, lactose, raffinose, sucrose, cellobiose, galactose. Grampositive, catalase negative rods that grew at $45^{\circ} \mathrm{C}$ or $10^{\circ} \mathrm{C}$ were considerd lactobacilli. Gram-positive, catalase negative cocci that grew in $6.5 \%$ at $45^{\circ} \mathrm{C}$ and $10^{\circ} \mathrm{C}$ were considered enterococci.

\section{MALDI-TOF-MS Profile Acquisition}

Identification of LAB had been confirmed by using matrix-assisted laser desorption/ Ionization time of flight mass spectrometry (MALDI-TOF-MS) in peptide and protein analyses.

One large colony of each of selected bacterial isolate (enough to fill about one half of a $10-\mu 1$ inoculating loop) was suspended in $70 \%$ ethanol in a $1.5 \mathrm{ml}$ microcenrtifuge tube and loaded three times onto ground steel MALDI target according to the manufacturer's instruction (Bruker Daltonics, Breman, Germany). Matching between experimental MALDI-TOF-MS profiles obtained from bacterial isolates and the reference MALDI-TOF-MS profiles is expressed by a BioTyper according to a Log (score) and an associated-color code (green, yellow and red). Briefly, a BioTyper log (score) exceeding 2.3 (green color) indicates a highly probable identification at the species level. A Log (score) between 2.0 and 2.3 means highly probable identification at the genus level (green color) and probable identification at the species level. A Log (score) between 1.7 and 2.0 (yellow color) implies only probable genus identification, while score value under 1.7 (red color) means no significant similarity between the unknown profile and any of those of the database. Micro Flex mass spectrometeries were performed at Academic Park, Faculty of Medicine, Alexandria, University, Egypt, according to Biswass and Rolain (2013) and Nacef et al. (2016).

\section{Characterization of Isolates Considered to Be Potential Probiotics}

Major selection criteria (resistance to low $\mathrm{pH}$, tolerance against bile, bile salt hydrolysis, haemolytic activity, pancreatin resistance, antibiotic resistance and antimicrobial activity) were used for the determination of probiotic properties of the selected isolates of lactic acid bacteria.

\section{Tolerence to low pH}

Tolerence to low $\mathrm{pH}$ is often indicative to stomach $\mathrm{pH}$ and was tested as described by Conway et al. (1987). Lactobacillus cultures were grown anaerobically in MRS agar medium (Difco) at $37 \pm 2^{\circ} \mathrm{C}$ overnight and transferred to fresh MRS broth for a further 16 - $18 \mathrm{hr}$., (to stationary phase). Cultures were centrifuged at $10000 \times \mathrm{g} / 10 \mathrm{~min} / 4^{\circ} \mathrm{C}$, washed once with sterile phosphate-buffered saline (PBS) NaCL, $0.8 \%$; $\left.\left.0.1 \mathrm{M} \mathrm{KH}_{2} \mathrm{PO}_{4}, \mathrm{pH} 7.2\right)\right\}$ and resuspended to one-tenth of the culture volume. These suspensions were used for the in vitro survival studies, by the addition of $0.1 \mathrm{ml}$ of each

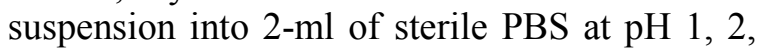
and 3 , and was maintained at $37 \pm 2^{\circ} \mathrm{C}$. The growth of the species was determined by absorbance at OD $620 \mathrm{~nm}$ after 0, 1.0, 2.0 and $3.0 \mathrm{hr}$., reflecting the time spent by food in the stomach (Bassyouni et al., 2012). Resistance percentage of species to stomach acid was determined by comparing optical denisty at zero time with optical denisty after $3 \mathrm{hr}$.

\section{Tolerance to bile salts}

The procedure of Klaenhammer and Kleeman (1981) was used to determine the tolerance of various species to bile (ox-bile) at final concentrations of $0,0.3,1.0 \% \mathrm{~W} / \mathrm{V}$ on solid MRS growth media, considering the fluctuation of bile concentrations at different times. 
Resistance was assessed in triplicates in terms of viable colony counts after incubation at $37 \pm 2{ }^{\circ} \mathrm{C}$ for zero and $4 \mathrm{hr}$., reflecting the time spent by food in the small intestine.

\section{Bile salt hydrolysis test}

Fresh bacterial cultures were streaked in triplicates on MRS agar containing $0.5 \%(\mathrm{~W} / \mathrm{V})$ taurodeoxycholic acid (TDCA, Sigma). The hydrolysis effect was indicated by partial hydrolysis, also plates were examined for white precipitates as a sign of bile hydrolysis after 48 hr., of anaerobic incubation at $37 \pm 2{ }^{\circ} \mathrm{C}$ (Argyri et al., 2013).

\section{Haemolytic activity test}

Fresh bacterial cultures were streaked on blood agar media containing 7\% $(W / V)$ human blood, and incubated at $37 \pm 2^{\circ} \mathrm{C}$ for $48 \mathrm{hr}$. Blood agar plates were examined for signs of $\beta$-haemolysis (clear zones around colonies), $\alpha$ - haemolysis (green-hued zones around colonies) or $\gamma$-haemolysis (no zones around colonies) (Hawaz, 2014).

\section{Tolerance to pancreatin}

Lactic acid bacteria species overnight (18 hr.) cultures were harvested by centifugation $\left(10,000 \times \mathrm{g}\right.$ at $4^{\circ} \mathrm{C}$ for $\left.5 \mathrm{~min}\right)$, washed twice with PBS (pH 7.2) then resuspended in PBS buffer solution $(\mathrm{pH} 8)$, containing pancreatin (Sigma-Aldrich) at $1 \mathrm{mg} / \mathrm{ml}$ concentration. Tolerance was assessed in terms of viable colony counts and enumerated after incubation at $37 \pm 2^{\circ} \mathrm{C}$ for zero time and after $4 \mathrm{hr}$., reflecting the time spent by food in the small intestine (Maragkoudakis et al., 2006).

\section{Antibiotic susceptibility test}

The antibiotic susceptibility test of the selected probiotic bacteria was determined towards 10 different antibiotics namely, penicillin $10 \mu \mathrm{g}$, ampicillin $10 \mu \mathrm{g}$, azithromycin $15 \mu \mathrm{g}$, erythromycin $15 \mu \mathrm{g}$, ciprofloxacin $5 \mu \mathrm{g}$, ofloxacin $5 \mu \mathrm{g}$, choloramphenicol $30 \mu \mathrm{g}$, tetracyclin $30 \mu \mathrm{g}$, gentamycin $10 \mu \mathrm{g}$, and streptomycin $10 \mu \mathrm{g}$ by using diffusion method. One milliliter of each actively growing cultures with an inoculum of approximately $10^{5} \mathrm{cfu} / \mathrm{ml}$ of each species was mixed throughly with $10 \mathrm{ml}$ of MRS agar and poured into Petri plates. After solidification, the antibiotic discs were placed on the solidified agar surface, and the plates were left for $15 \mathrm{~min}$ for diffusion of antibiotics, then incubated anaerobically at $37 \pm 2^{\circ} \mathrm{C}$ for $24 \mathrm{hr}$. Antibiotic susceptibility was determined according to methods described by NCCLS (2002). Diameters of the inhibition zones were measured by calipers in millimeters in which diameters is referred to as sensitive (S), intermediate (I) and resistant (R) (Vlkova et al., 2006).

\section{Antimicrobial activity test}

Antimicrobial activity of the selected probiotic bacteria against 6 pathogens (Staphylococcus aureus, E. coli, Klebsiella pneumoniae, Salmonella enteritidis, Pseudomonas aeruginosa and Candida albicans) was checked by using well diffusion assay according to Cardirici and Citak (2005) and Lailitha (2007). Species were tested for antimicrobial activity which were kindly provided by the Dept. of Microbiology, Faculty of Medicine, Zagazig Univ.

\section{Statistical Analyses}

Each treatment was run in three replicates and the results were statistically analysed by CoStat version 6.311 Copyright(c) 1998-2005 CoHort Software, http://www.cohort.com

\section{RESULTS AND DISCUSSION}

\section{Isolation and Preliminary Screening of Isolated LAB}

A total of 87 isolates were recovered i.e., 43 from dairy products, 15 from mixed pickles, 12 from human milk and 17 from infant stools as shown in Table 1, most of them were characterized as Gram positive, catalase negative and non spore forming bacteria. From the preliminary screening only 10 isolates out of 87 were selected based on their tolerance to high acidity according to Bassyouni et al. (2012). These 10 isolates which survived in low $\mathrm{pH}$ (1-3) for one to three hours were then identified using phenotypic and genotypic methods and subjected to in vitro characterization to evaluate their potential probiotic capacity.

\section{Identification of the Selected Isolates}

Morphological and biochemical characteristics were used to identify the 10 selected isolates 
Zagazig J. Agric. Res., Vol. 45 No. (1) 2018

Table 1. Number of LAB isolates and their sources

\begin{tabular}{lcc}
\hline Product abbreviation & No. of isolated LAB & Total percentage \\
\hline Yoghurt (Y) & 15 & 17.24 \\
Domiati cheese (DC) & 6 & 6.98 \\
Fresh raw milk (FRM) & 7 & 8.04 \\
Fermented milk (FM) & 15 & 17.24 \\
Mixed pickles (MP) & 11 & 12.64 \\
Green pickled olives (GPO) & 4 & 4.677 \\
Human milk (HM) & 12 & 13.79 \\
Infant stools (IS) & 17 & 19.54 \\
Total & 87 & $100 \%$ \\
\hline
\end{tabular}

(Table 2) according to Logan and De vos (2009). Gram positive and catalase negative isolates were considered as presumptive LAB. All the isolates were Gram positive, catalase negative and non-spore forming, eight isolates were negative for gas production from glucose and ammonia from arginine, contrarely to DC1 and DC5 were positive in both tests (gas from glucose and ammonia from arginine)which revealed that they are hetero-fermentative, while most of the isolates are homo-fermentative.

According to morphological and biochemical tests all of the isolates grew at $15^{\circ} \mathrm{C}$ except isolate IS9, IS10 and DC5, all isolates also grew at $45^{\circ} \mathrm{C}$ except isolates DC1 and MP7. Eight isolates tolerated $4 \%$ of $\mathrm{NaCl}$ concentration and also $6.5 \%$ but MP7 and DC5 did not. All the isolates fermented lactose and sucrose showed various fermentation levels to other carbohydrates. Based on these results, isolates HM1, IS3, FM4 and FM11 tend to be Lactobacillus paracaesi, IS1 Enterococcus faecium, DC1 Lactobacillus brevis, MP7 Lactobacillus plantarum, IS9.

\section{Direct identification of the Tested Bacteria Using MALDI-TOF-MS}

The above mentioned isolates were identified at Academic Park Fac. Medicine Alex. Univ., Egypt, using MALDI-TOF- MS. (matrixassisted lazer desorption ionization- time of flight mass spectrometry). Bacterial identification based on (MALDI)-time of flight (TOF) mass spectrometry (MS) is becoming a method of choice for determining the genus, species and even subspecies of bacterial isolates (Carbonnelle et al., 2012; Dušková et al., 2012). Also, this technology is achievable for other microorganisms (e.g. yeasts, fungi,) from various sources (Chalupová et al., 2014). Using this advanced method, the identification was confirmed and the prospective species with their numbers as conserved in the International Cultural Center for Microorganisms. The score values for the bacterial isolates are shown in Table 3. All of the isolates showed a score value between 2.000 to $2.484(100 \%)$ and were correctly identified to genus and species levels. All the tested bacterial species were type species that are included in the Bruker Database, and all spectrum scores were greater than 2.0. Thus, all of the tested LAB were correctly identified to genus and species levels with biotype software score values greater than 2.0 , and all of them had high degree of precision. (Bizzini et al., 2010; Wang et al., 2013) reported that the $16 \mathrm{~S}$ rRNA sequencing results agreed with MALDITOF- MS identification in most cases presumably owing to co-evolution of ribosomal proteins and ribosomal nucleic acids.

\section{Survival Under Condition Simulating the Human GI Tract}

As probiotic, LAB must be able to survive in the acidic conditions in the stomach and resist bile acids at the beginning of the small intestine (Argyri et al., 2013). 
Nader, et al.

Table 2. Some morphological and biochemical characteristics of the selected LAB isolates

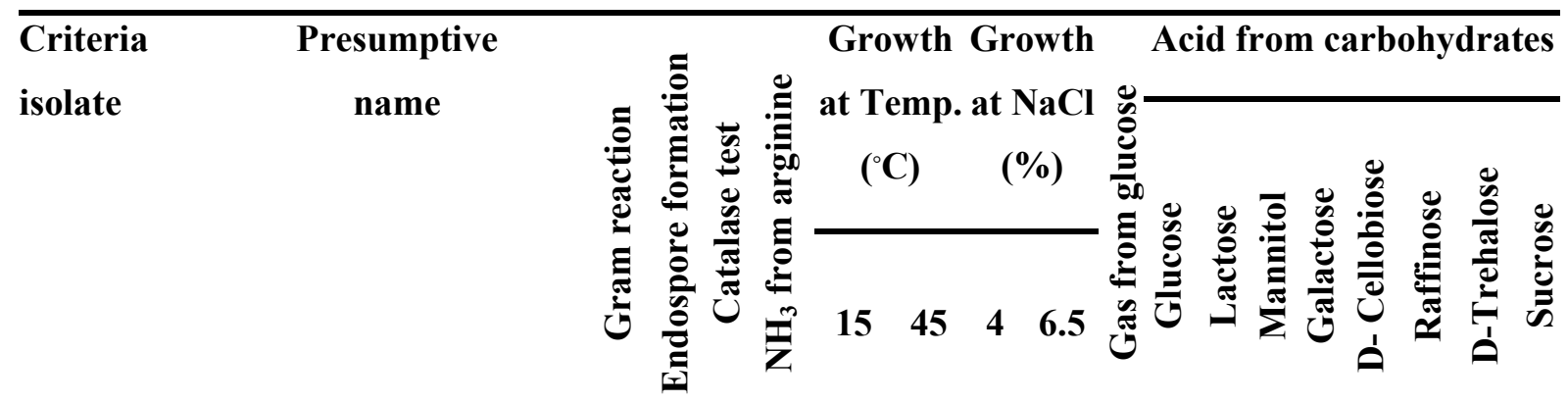

\begin{tabular}{|c|c|c|c|c|c|c|c|c|c|c|c|c|c|c|c|c|c|}
\hline HM 1 & L. paracasei & + & & - & - & + & + & + & + & - & + & + & + & + & + & - & -+ \\
\hline IS 1 & Enterococcus faecium & + & - & - & - & + & + & + & + & - & + & + & - & - & + & - & ++ \\
\hline IS 3 & L. paracasei & + & - & - & - & + & + & + & + & - & + & + & + & + & + & - & - \\
\hline DC 1 & L. brevis & + & - & - & + & + & - & + & + & + & - & + & - & + & - & + & -+ \\
\hline FM 4 & L. paracasei & + & - & - & - & + & + & + & + & - & + & + & + & + & + & - & - \\
\hline FM 11 & L. paracasei & + & - & - & - & + & + & + & + & - & + & + & + & + & + & - & - \\
\hline MP 7 & L. plantarum & + & - & - & - & + & - & + & - & - & + & + & - & - & + & + & - \\
\hline IS 9 & L. acidophilus & + & - & - & - & - & + & + & + & - & + & + & - & - & + & + & + \\
\hline IS 10 & Bifidobacterium bifidium & + & - & - & - & - & + & + & + & - & + & + & - & + & - & - & - \\
\hline DC 5 & L. fermentum & + & - & - & + & - & + & + & - & + & + & + & + & + & - & + & - \\
\hline
\end{tabular}

L.:Lactobacillus

Table 3. Rate classification results as determined by Bruker Daltonik MALDI Biotyper

\begin{tabular}{|c|c|c|c|}
\hline Isolate code & Analyte name & Organism(best match) & Score value \\
\hline IS 9 & $(++)(\mathbf{A})$ & Lactobacillus acidophilus DSM 20242 DSM & 2.213 \\
\hline HM 1 & $(++)(A)$ & Lactobacillus paracasei ssp paracasei DSM 20312 DSM & 2.175 \\
\hline DC 1 & $(++)(\mathbf{A})$ & Lactobacillus brevis DSM 2647 DSM & 2.122 \\
\hline IS 3 & $(++)(A)$ & Lactobacillus paracasei ssp paracasei DSM 20006 DSM & 2.046 \\
\hline IS 1 & $(+++)(\mathbf{A})$ & Enterococcus faecium $11037 \mathrm{CHB}$ & 2.484 \\
\hline FM 4 & $(++)(\mathbf{A})$ & Lactobacillus paracasei ssp paracasei DSM 20244 DSM & 2.165 \\
\hline FM 11 & $(++)(\mathbf{A})$ & Lactobacillus paracasei ssp paracasei DSM 20207 DSM & 2.145 \\
\hline MP 7 & $(++)(\mathbf{A})$ & Lactobacillus plantarum DSM 2601 DSM & 2.116 \\
\hline IS 10 & $(++)(\mathbf{A})$ & Bifidobacterium bifidium DSM 27651 DSM & 2.224 \\
\hline DC 5 & $(++)(\mathbf{A})$ & Lactobacillus fermentum DSM 12341 DSM & 2.165 \\
\hline
\end{tabular}

- Category A= species consistency (2.300-3.000). DSM: Deutsche Sammlung Von Mikroorganismen. 


\section{Tolerance to low pH}

From Table 4, it can be shown that the 10 LAB were highly tolerant to $\mathrm{pH} 3$ for three hours as 8 species remained viable when determined by absorbance at OD $620 \mathrm{~nm}$. These results are in agreement with those obtained by Du Toit et al. (1998), Jacobsen et al. (1999), Maragkoudakis et al. (2006), Xanthopoulos et al. (2012) and Argyri et al. (2013) who reported that Lactobacillus species in food or animal and human origin were able to retain their viability when exposed to $\mathrm{pH}$ values of 2- 4 .

Tolerance to bile salts and bile salts hydrolysis

Another key characteristic of probiotic bacteria is their tolerance and ability to grow in the presence of bile salts in order to survive in the digestive system. Although the bile concentration of the human gastrointestinal tract varies, the mean intestinal bile concentration is believed to be $0.3 \%(\mathrm{~W} / \mathrm{V})$ and the staying time is suggested to be $4 \mathrm{hr}$., (Parasad et al., 1999). Results in Table 5 show that the majority of the tested species are resistant to bile salts even after $4 \mathrm{hr}$, of exposure, retaining their viability with negligible reduction in viable counts $(\leq 1 \mathrm{log}$ cycle). However, the numbers of nine of them showed decreases in their numbers ranging from $\log 0.9$ to $\log 1.95$. L. fermentum DC5 only showed negligible decrease. This is an important observation indicating that these species will not only survive in vivo in the low $\mathrm{pH}$ of the stomach but may be able to grow and colonize in the high bile environment in the intestine. These results are in harmony with those of Jensen et al. (2012), who reported that Lactobacillus species tolerate gastric juice well with no reduction in viability.

Some species of LAB secrete bile salt hydrolase enzyme, which hydrolyses conjugated bile acids to release de-conjugated bile acids and amino acids (Begley et al., 2006; Sridevi $\boldsymbol{e t}$ al., 2009; Franz et al., 2011). When these salts are secreted from the gastrointestinal tract, the demand for cholesterol is increased, which in turn lowers cholesterol levels (Driessen and de Boer, 1989; De Rodas et al., 1996).

\section{Tolerance to pancreatin}

From Table 6 it can be shown that all species survived in the presence of $1 \mathrm{mg} / \mathrm{ml}$ pancreatin for $4 \mathrm{hr}$., confirming their ability to survive in the passage through the GI tract well. However, their numbers dropped especially those of $L$. acidophilus IS9 and L.paracasei FM11. Specie L. paracasei HM1 showed the highest tolerance (the drop was from $\log 8.51$ to 8.45).These results are in agreement with Mansour et al. (2014), found that Enterococcus faecium NM1 13, NM2 13 and Lactobacillus casei NM5 12 showed high tolerance to low $\mathrm{pH}$, bile salts and pancreatic enzymes.

\section{Haemolytic activity}

The results in Table 6 revealed that 8 species are non-hemolytic, while 2 of them ( $L$. paracasei FM4 and L. plantarum MP7) induced $\alpha$-haemolysis. Non haemolytic species are considered as a safe prerequisite for the selection of a probiotic species (Hawaz, 2014).

\section{Resistance to antibiotics}

The antibiotic resistance profile was carried out with ten antibiotics belongs to three different groups depending on their mode of action as following: ampicillin and pencillin $10 \mu \mathrm{g}$ (cell wall synthesis inhibitors), ciprofloxacin and ofloxacin $5 \mu \mathrm{g}$ (DNA synthesis inhibitors), gentamycin $10 \mu \mathrm{g}$, streptomycin $10 \mu \mathrm{g}$, tetracyclin $30 \mu \mathrm{g}$ (Anti 30S ribosomal subunit) and azithromycin $15 \mu \mathrm{g}$, erythromycin $15 \mu \mathrm{g}$ and chloramphenicol $30 \mu \mathrm{g}$ (Anti 50S ribosomal subunit). All the tested LAB species were resistant to penicillin, ciprofloxacin, gentamycin and streptomycin. Enterococcus faecium, Bifidobacterium bifidium, $L$. plantarum, $L$. acidophilus, L. fermentum and L. paracasei IS3 were resistant to all antibiotics but intermediate to ampicillin and chloramphenicol. Other Lactobacillus species showed variable resistance to the tested antibiotics according to the National Committee for Clinical Laboratory Standards (NCCLS, 2002) as shown in Table 7. Maragkoudakis et al. (2006) examined 29 Lactobacillus species for their probiotic potential and found that the majority of species were resistant to vancomycin but sensitive to chloramphenicol and tetracycline. Xanthopoulos et al. (2012) evaluated antibiotic susceptibility of 8 isolates and found some variations of susceptibility between isolates. 
Table 4. Tolerance of LAB species to low $\mathrm{pH}$ and their survival percentage

\begin{tabular}{|c|c|c|c|c|c|c|}
\hline \multirow[t]{2}{*}{$\overline{\text { LAB specie code }}$} & \multirow[t]{2}{*}{ pH } & \multicolumn{4}{|c|}{ OD at $620 \mathrm{~nm}$ at different periods (hr.) } & \multirow[t]{2}{*}{ Survival (\%) } \\
\hline & & $\overline{\mathbf{0}}$ & 1 & 2 & $\overline{3}$ & \\
\hline & 1 & 1.120 & 0.404 & 0.259 & 0.240 & 21 \\
\hline \multirow[t]{3}{*}{ IS 1} & 2 & 1.070 & 0.803 & 0.701 & 0.700 & 64 \\
\hline & 3 & 1.080 & 0.971 & 0.960 & 0.927 & 86 \\
\hline & 1 & 0.764 & 0.712 & 0.736 & 0.573 & 75 \\
\hline \multirow[t]{3}{*}{ IS 3} & 2 & 0.766 & 0.735 & 0.675 & 0.622 & 81 \\
\hline & 3 & 0.767 & 0.751 & 0.770 & 0.631 & 82 \\
\hline & 1 & 0.144 & 0.121 & 0.097 & 0.051 & 35 \\
\hline \multirow[t]{3}{*}{ IS 9} & 2 & 0.145 & 0.139 & 0.112 & 0.100 & 68 \\
\hline & 3 & 0.148 & 0.141 & 0.135 & 0.120 & 81 \\
\hline & 1 & 0.152 & 0.079 & 0.077 & 0.073 & 48 \\
\hline \multirow[t]{3}{*}{ IS 10} & 2 & 0.150 & 0.139 & 0.100 & 0.078 & 51 \\
\hline & 3 & 0.150 & 0.140 & 0.132 & 0.130 & 86 \\
\hline & 1 & 0.313 & 0.250 & 0.183 & 0.161 & 51 \\
\hline \multirow[t]{3}{*}{ FM 4} & 2 & 0.311 & 0.267 & 0.244 & 0.243 & 78 \\
\hline & 3 & 0.313 & 0.275 & 0.269 & 0.256 & 81 \\
\hline & 1 & 0.227 & 0.186 & 0.177 & 0.173 & 67 \\
\hline \multirow[t]{3}{*}{ FM 11} & 2 & 0.236 & 0.198 & 0.196 & 0.160 & 76 \\
\hline & 3 & 0.228 & 0.211 & 0.203 & 0.198 & 86 \\
\hline & 1 & 1.254 & 0.935 & 0.899 & 0.878 & 70 \\
\hline \multirow[t]{3}{*}{ HM 1} & 2 & 1.236 & 0.988 & 0.913 & 0.900 & 72 \\
\hline & 3 & 1.248 & 1.484 & 1.183 & 1.001 & 80 \\
\hline & 1 & 0.499 & 0.280 & 0.255 & 0.229 & 45 \\
\hline \multirow[t]{3}{*}{ MP 7} & 2 & 0.501 & 0.461 & 0.448 & 0.357 & 71 \\
\hline & 3 & 0.500 & 0.482 & 0.472 & 0.410 & 82 \\
\hline & 1 & 1.194 & 0.875 & 0.815 & 0.746 & 62 \\
\hline \multirow[t]{3}{*}{ DC 1} & 2 & 1.197 & 1.059 & 0.865 & 0.806 & 67 \\
\hline & 3 & 1.196 & 1.115 & 1.025 & 1.002 & 83 \\
\hline & 1 & 0.264 & 0.205 & 0.200 & 0.187 & 70 \\
\hline \multirow[t]{2}{*}{ DC 5} & 2 & 0.267 & 0.245 & 0.243 & 0.194 & 72 \\
\hline & 3 & 0.268 & 0.256 & 0.248 & 0.223 & 83 \\
\hline LSD 0.05 & & 0.00120 & 0.00332 & 0.00116 & 0.0033 & \\
\hline
\end{tabular}

OD: optical density, (\%) of survival is calculated by dividing the OD of $3 \mathrm{hr}$., to $0 \mathrm{hr}$ at $\mathrm{pH} 3$ 
Zagazig J. Agric. Res., Vol. 45 No. (1) 2018

Table 5. Tolerance of selected species to bile salts and bile salt hydrolysis (BSH)

\begin{tabular}{|c|c|c|c|c|c|c|c|}
\hline \multirow[t]{3}{*}{$\overline{\text { LAB specie }}$} & \multirow{2}{*}{\multicolumn{3}{|c|}{\begin{tabular}{c|} 
Log at $0 \mathrm{hr}$. \\
Bile salt concentration
\end{tabular}}} & \multirow{2}{*}{\multicolumn{3}{|c|}{$\begin{array}{c}\text { Log at } 4 \mathrm{hr} . \\
\text { Bile salt concentration }\end{array}$}} & \multirow{3}{*}{$\begin{array}{r}\text { Bile salt } \\
\text { hydrolysis } \\
(\text { BSH })\end{array}$} \\
\hline & & & & & & & \\
\hline & $0.0 \%$ & $0.3 \%$ & $1.0 \%$ & $0.0 \%$ & $0.3 \%$ & $1.0 \%$ & \\
\hline L. paracaseiHM1 & 8.99 & 8.90 & 6.80 & 7.92 & 6.08 & 5.61 & 1 \\
\hline E. faecium IS1 & 8.34 & 7.76 & 6.09 & 7.68 & 6.30 & 5.73 & 1 \\
\hline L. paracasei IS3 & 8.41 & 6.93 & 6.05 & 7.99 & 6.60 & 5.83 & 0 \\
\hline L. brevis DC1 & 8.40 & 7.19 & 6.02 & 7.35 & 6.39 & 5.93 & 0 \\
\hline L. paracasei FM4 & 8.04 & 6.59 & 5.76 & 7.83 & 5.88 & 5.57 & 0 \\
\hline L. plantarum MP7 & 8.28 & 6.79 & 5.98 & 7.67 & 5.95 & 5.52 & 1 \\
\hline L. acidophils IS9 & 8.64 & 7.27 & 4.92 & 7.37 & 5.26 & 4.70 & 0 \\
\hline Bifid. bifidium IS10 & 8.40 & 7.86 & 5.68 & 8.21 & 6.48 & 5.43 & 1 \\
\hline L. fermentm DC5 & 8.21 & 7.92 & 7.05 & 7.97 & 7.91 & 6.75 & 0 \\
\hline L. paracasei FM11 & 8.82 & 6.99 & 5.13 & 7.10 & 5.35 & 4.68 & 0 \\
\hline LSD 0.05 & & 0.00927 & & & 0.00910 & & \\
\hline
\end{tabular}

L: Lactobacillus, E: Enterococcus, Bifid: Bifid bacterium, 0: no hydrolysis, 1: partial hydrolysis

Table 6. Tolerance to pancreatin $(1 \mathrm{mg} / \mathrm{ml})$ and haemolytic activity

\begin{tabular}{lccc}
\hline LAB specie & Log at zero time & Log after $\mathbf{4}$ hr. & Haemolytic activity \\
\hline L. paracasei HM1 & 8.51 & 8.45 & $\gamma$ \\
E. faecium IS1 & 8.24 & 7.35 & $\gamma$ \\
L. paracasei IS3 & 8.38 & 7.56 & $\gamma$ \\
L. brevis DC1 & 8.37 & 8.13 & $\gamma$ \\
L. paracasei FM4 & 7.97 & 7.74 & $\alpha$ \\
L. plantarum MP7 & 8.19 & 7.52 & $\alpha$ \\
L. acidophilus IS9 & 8.56 & 7.32 & $\gamma$ \\
Bifid. bifidium IS10 & 8.35 & 7.52 & $\gamma$ \\
L.fermentum DC5 & 8.05 & 7.39 & $\gamma$ \\
L. paracasei FM11 & 8.76 & 7.67 & $\gamma$ \\
LSD 0.05 & 0.00983 & 0.00883 & \\
\hline
\end{tabular}

L: Lactobacillus, E: Enterococcus, Bifid: Bifidobacterium $\quad \gamma$ : no zone $\alpha$ : greenish zone 
Although probiotics with the resistance genes may increase the risk of potential transfer in gut, in this respect antibiotic-resistant probiotic may be advantageous in the case of antibiotic administration to human and animal and the establishment of the beneficial microorganisms in the gut for prolonged periods (Kim and Austin, 2008). The natural resistance of the isolates for clinically important antibiotics may provide a way for the development of antibiotic/ probiotic combination therapies for condition like diarrhea, female urogenital tract infection and infective endocarditis (Charteris et al., 1998b).

\section{Antimicrobial activity}

The cell free supernatants of LAB species were tested for antimicrobial activity against 6 pathogens, Staphylococcus aureus, E. coli, Klebsiella pneumoniae, Salmonella entritides, Pseudomonas aeruginosa, Candida albicans by using well diffusion method.

From Table 8 it can be shown that the spectrum of inhibition was different among the tested species. L. acidophilus (IS9) showed the highest antimicrobial activity against all the tested pathogens. Also E. faecium (IS1), $L$. plantarum (MP7) Bifidobacterium bifidium (IS10) and L. fermentum (DC5) showed antimicrobial property against all the tested pathogens except Candida albicans, with highest inhibition zone against $E$. coli $(18,17,19$ and $22 \mathrm{~mm}$, respectively).

Similar results were also reported by Araujo and Ferreira (2013) and Francois et al. (2013) on E. faecium and L. plantarum against spoilage and pathogenic bacteria. Also, Abdel - Raouf et $\boldsymbol{a l}$ (2017) showed that LAB isolated from salted fish and mixed pickles had a good antimicrobial activity against Salmonella entritides and E. coli (Gram negative) which are major food borne pathogens. However Yateem et al. (2008) reported that $\mathrm{LAB}$ are capable of producing antimicrobial compounds such as formic and benzoic acids, hydrogen peroxide, diacetyl, acetoine and bacteriocins such as nicin.

The production levels and the proportions among those compounds depend on the specie, medium compounds and physical parameters (Tannock, 2004). The inhibitory activities of LAB against Gram positive pathogens have been mostly shown to be due to the bactericidal effect of protease sensitive bacteriocins (Jack and Tagg, 1995). However, the antagonistic effects of LAB towards Gram negative pathogens could be related to the production of organic acids and hydrogen peroxide (Ito et al., 2003).

Table 7. Susceptibility of potentially LAB to antibiotics using the disc diffusion method (diameter of inhibition zone in $\mathrm{mm}$ )

\begin{tabular}{|c|c|c|c|c|c|c|c|c|c|c|}
\hline \multirow{3}{*}{$\begin{array}{c}\text { LAB } \\
\text { species }\end{array}$} & \multirow{2}{*}{\multicolumn{2}{|c|}{$\begin{array}{l}\text { Cell wall } \\
\text { synthesis } \\
\text { inhibitors }\end{array}$}} & \multirow{2}{*}{\multicolumn{2}{|c|}{$\begin{array}{l}\text { DNA synthesis } \\
\text { inhibitors }\end{array}$}} & \multicolumn{6}{|c|}{ Protein synthesis inhibitors } \\
\hline & & & & & \multicolumn{3}{|c|}{ Anti-30S ribosomal subunit } & \multicolumn{3}{|c|}{ Anti-50S ribosomal subunit } \\
\hline & $\begin{array}{c}\text { Ampicillin } \\
10 \mu \mathrm{g}\end{array}$ & $\begin{array}{c}\text { Penicillin } \\
10 \mu g\end{array}$ & $\begin{array}{c}\text { Ciprofloxacin } \\
5 \mu \mathrm{g}\end{array}$ & $\begin{array}{l}\text { Ofloxacin } \\
5 \mu \mathrm{g}\end{array}$ & $\begin{array}{c}\text { Gentamycin } \\
10 \mu \mathrm{g}\end{array}$ & $\begin{array}{c}\text { Streptomycin } \\
10 \mu \mathrm{g}\end{array}$ & $\begin{array}{l}\text { Tetracycline } \\
30 \mu \mathrm{g}\end{array}$ & $\begin{array}{l}\text { Azithromycin } \\
15 \mu \mathrm{g}\end{array}$ & $\begin{array}{c}\text { Erythromycin } \\
15 \mu \mathrm{g}\end{array}$ & $\begin{array}{c}\text { Chloramphenicol } \\
30 \mu \mathrm{g}\end{array}$ \\
\hline HM 1 & $23(\mathrm{~S})$ & $20(\mathrm{R})$ & $10(\mathrm{R})$ & $12(\mathrm{R})$ & $8(\mathrm{R})$ & $0(\mathrm{R})$ & $16(\mathrm{I})$ & $18(\mathrm{I})$ & $20(\mathrm{I})$ & $21(\mathrm{~S})$ \\
\hline IS 1 & $14(\mathrm{I})$ & $14(\mathrm{R})$ & $0(\mathrm{R})$ & $8(\mathrm{R})$ & $0(\mathrm{R})$ & $0(\mathrm{R})$ & $12(\mathrm{R})$ & $12(\mathrm{R})$ & $12(\mathrm{R})$ & $15(\mathrm{I})$ \\
\hline IS 3 & $14(\mathrm{I})$ & $15(\mathrm{R})$ & $0(\mathrm{R})$ & $7(\mathrm{R})$ & $0(\mathrm{R})$ & $0(\mathrm{R})$ & $14(\mathrm{R})$ & $12(\mathrm{R})$ & $13(\mathrm{R})$ & $14(\mathrm{I})$ \\
\hline DC 1 & $20(\mathrm{~S})$ & $19(\mathrm{R})$ & $9(\mathrm{R})$ & $12(\mathrm{R})$ & $8(\mathrm{R})$ & $0(\mathrm{R})$ & $16(\mathrm{I})$ & $14(\mathrm{R})$ & $18(\mathrm{I})$ & $17(\mathrm{I})$ \\
\hline FM 4 & $21(\mathrm{~S})$ & $20(\mathrm{R})$ & $8(\mathrm{R})$ & $13(\mathrm{I})$ & $0(\mathrm{R})$ & $0(\mathrm{R})$ & $17(\mathrm{I})$ & $16(\mathrm{I})$ & $17(\mathrm{I})$ & $20(\mathrm{~S})$ \\
\hline FM 11 & $15(\mathrm{~S})$ & $19(\mathrm{R})$ & $8(\mathrm{R})$ & 15 (I) & $0(\mathrm{R})$ & $0(\mathrm{R})$ & $12(\mathrm{R})$ & 17 (I) & $16(\mathrm{I})$ & 15 (I) \\
\hline MP 7 & $14(\mathrm{I})$ & $15(\mathrm{R})$ & $0(\mathrm{R})$ & $8(\mathrm{R})$ & $0(\mathrm{R})$ & $0(\mathrm{R})$ & $11(\mathrm{R})$ & $11(\mathrm{R})$ & $13(\mathrm{R})$ & 12 (I) \\
\hline IS 9 & $13(\mathrm{I})$ & $15(\mathrm{R})$ & $7(\mathrm{R})$ & $8(\mathrm{R})$ & $0(\mathrm{R})$ & $0(\mathrm{R})$ & $10(\mathrm{R})$ & $10(\mathrm{R})$ & $11(\mathrm{R})$ & $16(\mathrm{I})$ \\
\hline IS 10 & 14 (I) & $14(\mathrm{R})$ & $0(\mathrm{R})$ & $8(\mathrm{R})$ & $0(\mathrm{R})$ & $0(\mathrm{R})$ & $13(\mathrm{R})$ & $13(\mathrm{R})$ & $12(\mathrm{R})$ & 15 (I) \\
\hline DC 5 & $13(\mathrm{I})$ & $15(\mathrm{R})$ & $0(\mathrm{R})$ & $0(\mathrm{R})$ & $0(\mathrm{R})$ & $0(\mathrm{R})$ & $10(\mathrm{R})$ & $12(\mathrm{R})$ & $13(\mathrm{R})$ & 14 (I) \\
\hline
\end{tabular}

R: resistant $\quad$ I: intermediate $\quad$ S: sensitive 
Zagazig J. Agric. Res., Vol. 45 No. (1) 2018

Table 8. Antimicrobial activities of cell - free extract of selected LAB against various indicator pathogens in terms of the diameter of inhibition zone $(\mathrm{mm})$

\begin{tabular}{lcccccc}
\hline \multicolumn{1}{c}{ Pathogen } & $\begin{array}{c}\text { Staphylococcus } \\
\text { aureus }\end{array}$ & $\begin{array}{c}\text { Klebsiella } \\
\text { pneumoniae }\end{array}$ & $\begin{array}{c}\text { Salmonella Pseudomonas } \\
\text { entritidis }\end{array}$ & $\begin{array}{c}\text { E. } \\
\text { aeruginosa }\end{array}$ & $\begin{array}{c}\text { Candida } \\
\text { colbicans }\end{array}$ \\
\hline LAB species & 12 & 0 & 0 & 10 & 14 & 0 \\
E. paracasei HM1 & 10 & 12 & 8 & 15 & 18 & 0 \\
L. paracasei IS3 & 10 & 0 & 0 & 12 & 8 & 0 \\
L. brevis DC1 & 16 & 0 & 10 & 14 & 10 & 0 \\
L. paracasei FM4 & 7 & 10 & 0 & 5 & 13 & 0 \\
L. pracasei FM11 & 8 & 0 & 0 & 11 & 11 & 0 \\
L. acidophilus IS9 & 20 & 21 & 18 & 19 & 18 & 14 \\
L. plantarum MP7 & 16 & 17 & 8 & 16 & 17 & 0 \\
Bifid. bifidium IS10 & 10 & 16 & 12 & 15 & 19 & 0 \\
L. fermentum DC5 & 22 & 14 & 18 & 17 & 22 & 0 \\
\hline
\end{tabular}

\section{REFERENCES}

Abdel-Raouf, B.A., H.M. Abd El-Basit, M.I. Hegazy and S.A. Mahgoub (2017). Probiotic properties of lactic acid bacteria isolated from Egyptian salted foods. Zagazig J. Agric. Res., 44 (4): 1289-1302.

Araujo, T.F. and C.L.F. Ferreira (2013). The Genus Enterococcus as probiotic: Safety concerns. Braz. Arch. Biol. Technol., 56 (3): 457-466.

Argyri, A.A., G. Zoumpopoulou, A.G. Kimono, K.A. Karatzas, E. Tsakalidou, G.J. Nychas, E. Panagou and C. Tassou (2013). Selection of potential probiotic lactic acid bacteria from fermented olives by in vitro tests. Food Microbiol., 33:282-291.

Bao, Y., Y. Zhang, Y. Liu, S. Wang, X. Dong, Y. Wang and H. Zhang (2010). Screening of potential probiotic properties of Lactobacillus fermentum isolated from traditional dairy products. Food Control, 21: 695-701.

Bassyouni, R.H., S.A. Walla, G.F. Mostafa, A. Saed and K. Zeinat (2012). Characterization of lactic acid bacteria isolated from dairy products in Egypt as a probiotic. Life Sci. J., 9 (4): 2924-2933.

Begley, M., C. Hill and C.G. Gahan (2006). Bile salt hydrolase activity in probiotics. Appl. Environ. Microbiol., 72: 1729-1738.

Biswass, S. and J.M. Rolain (2013). Use of MALDI-TOF mass spectrometry for identification of bacteria that are difficult to culture. J. Microbiol. Methods, 92:14-24.

Bizzini, A., C. Durussel, J. Bille, G. Greub, and G. Prod'hom (2010). Performance of matrixassisted laser desorption ionization-time of flight mass spectrometry for identification of bacterial species routinely isolated in a clinical microbiology laboratory. J. Clin. Microbiol., 48:1549-1554.

Carbonnelle, E., P. Grohs, H. Jacquier, N. Day, S. Tenza, A. Dewailly, O. Vissouarn, M. Rottman, J.-L. Herrmann, I. Podglajen and L. Raskine (2012). Robustness of two MALDITOF mass spectrometry systems for bacterial identification. J. Microbiol. Methods, 89: 133-136. http://dx.doi. org/10.1016/j. mimet. 2012.03.003.

Cardirici, B.H. and S. Citak (2005). A comparison of two methods used for 
measuring antagonistic activity of lactic acid bacteria. Paki. J. Nut., 4 (4): 237-241.

Chalupová, J., M. Raus, M. Sedlářová and M. Šebela (2014). Identification of fungal microorganisms by MALDI-TOF mass spectrometry. Biotechnol. Adv., 32: 230241. http://dx. doi.org/10.1016 /j. biotechadv. 2013.11.002.

Charteris, P.W., M.P. Kelly, L. Morelli and K.J. Collins (1998a). Development and application of an in vitro methodology to determine the transit tolerence of potentially probiotic Lactobacillus and Bifidobacterium species in the upper man gastrointestinal tract. J. Appl. Microbiol., 84: 759-768.

Charteris, W.P., P.M. Kelly, L. Morelli and J. K. Collins ( 1998b). Antibiotic susceptibility of potentially probiotic Lactobacillus species. J. Food Prot., 61: 1636-1643

Clemente, J.C., L.K. Ursell, L.W. Parfrey and R. Knight (2012). The impact of the gut microbiota on human health: an integrative view. Cell., 148:1258-70.

Conway, P.L., S.L. Gorbach and B.R. Goldin (1987). Survival of lactic acid bacteria in the human stomach and adhesion to intestinal cells. J. Dairy Sci., 70 (1): 1-12.

De Rodas, B.Z., S.E. Gilliland and C.V. Maxwell (1996). Hypocholesterolemic action of Lactobacillus acidophilus ATCC 43121 and calcium in swine with hypocholesterolemia induced by diet. J. Dairy Sci., 79: 2121- 2128.

De Vrese, M. and J. Schrezenmeir (2008). Probiotics, prebiotics, synbiotics. Adv. Biochem., 111:1-66.

De Vuyst, L.D., G. Falony and F. Leroy (2008). Probiotics in fermented sausages. Meat Sci., 80: 75-78.

Diba, F.S., M.H. Khondoker, M.A. Azim and M.H. Md (2013). Isolation characterization and determination of antimicrobial properties of lactic acid bacteria from human milk. Jordan J. Biol. Sci., 15(6): 111-116.

Driessen, F.M. and R. de Boer (1989). Fermented milks with selected intestinal bacteria: a healthy trend in new products. Neth. Milk Dairy J., 43: 367-382.

Du Toit, M., C.M. Franz, L.M. Dicks, U. Schillinger, P. Haberer, B. Warlies, F. Ahrens and W.H. Holzapfel (1998). Characterisation and selection of probiotic lactobacilli for a preliminary minipig feeding trial and their effect on serum cholestrerol levels, faeces $\mathrm{pH}$ and faeces moisture content. Int. J. Food Microbiol., 40: 93-104.

Dušková, M., O. Šedo, K. Kšicová, Z. Zdráhal and R. Karpíšková (2012). Identification of lactobacilli isolated from food by genotypic methods and MALDI-TOF MS. Int. J. Food Microbiol., 159, 107-114.http:// dx.doi. org/ 10.1016/j.ijfoodmicro.2012.07.029.

Espeche, M.C., M. Pellegrino, I. Frola, A. Larriestra, C. Bogni and M.E.F. NaderMacías (2012). Lactic acid bacteria from raw milk as potentially beneficial species to prevent bovine mastitis. Anaerobe, 18: 103109.

FAO/WHO (2002). Joint FAO/WHO working group report on drafting guidelines for the evaluation of probiotics in food. London, Ontario, Canada, April 30 and May 1,2002.

Francois, Z.N., K.P. Marie, T.A.H. Noelle and G.W.R. Emeric (2013). Antimicrobial activity of bacteriocin produced by Lactobacillus plantarum $29 \mathrm{~V}$ and species viability in palm kernel oil. Int. J. Nut. Food Sci., 2 (3):102-108.

Franz, C.M., M. Huch, H. Abriouel, W. Holzapfel and A. Gálvez (2011). Enterococci as probiotics and their implications in food safety. Int. J. Food Microbiol., 151 (2): 125140.

Hawaz, E. (2014). Isolation and identification of probiotic lactic acid bacteria from curd and in vitro evaluation of its growth inhibition activities against pathogenic bacteria. Afri. J. Microbiol. Res., 8 (13): 1419-1425.

Hobbs, C. (2000). Prolife therapy with probiotics. Health World Online (Online at: http:// www. healthy.net/asp/templates/ article. asp 22:930 - 953). 
Husmaini, A., M.H. Purwati, E. Yuniza and A. Alimon (2011). Growth and survival of lactic acid bacteria isolated from byproduct of virgin coconut oil as probiotic candidate for poultry. Int. J. Poult. Sci., 10: 309-314.

Ito, A., G. Buch and P. Tian (2003). The screening of hydrogen peroxide-producing lactic acid bacteria and their application to inactivating psychrotrophic food-born pathogens. J. Curr. Microbiol., 47: 231-236.

Jack, R.W. and J.R. Tagg (1995). Bacteriocins of gram-positive bacteria. Microbiol. Rev., 59: 171-200.

Jacobsen, C.N., V. Rosenfeldt Nielsen, A.E. Hayford, P.L. Moller, K.F. Michaelsen, A. Paerregaard, B. Sandstrom, M. Tvede and M. Jakobsen (1999). Screening of probiotic activities of forty-seven species of Lactobacillus spp. by in vitro techniques and evaluation of the colonization ability of five selected species in humans. Appl. Environ. Microbiol., 65: 4949-4956

Jensen, H., S. Grimmer, K. Naterstad and L. Axelsson (2012). In vitro testing of commercial and potential probiotic lactic acid bacteria. Int. J. Food Microbiol., (153): 216-222.

Johansson, M.L., G. Molin, B. Jeppson, S. Nobaek and S. Ahrne' S Bengmark (1993). Administration of different Lactobacillus species in fermented oatmeal soup In vivo colonization of human intestinal mucosa and effect on the indigenous flora. Appl. Environ. Microbiol., 59: 15-20

Kim, D.H. and B. Austin (2008). Characterization of probiotic carnobacteria isolated from rainbow trout (Oncorhynchus mykiss) intestine. Lett. Appl. Microbiol., 47: 141-7.

Klaenhammer, T.R. and E.G. Kleeman (1981). Growth characteristics, bile sensitivity, and freeze damage in colonial variants of $L$. acidophilus. Appl. and Environ. Microbiol., 41: 1461-1467.

Lailitha, M.K. (2007). Manual on Antimicrobial Susceptibility Testing. Retrived January 3, from http://www. ijmm.org/ documents/ Antimicrobial.doc.
Lebeer, S., J. Vanderleyden and S.C. De Keersmaecker (2008). Genes and molecules of lactobacilli supporting probiotic action. Microbiol. Mol. Biol. Rev., 72: 728-764

Lilly, D.M. and R.H. Stillwell (1965). Probiotics: growth-promoting factors produced by microorganisms. Sci., 147: 747-748

Logan, N.A. and P. De vos (2009). Genus 1Bacillus Cohn 1872. In: Bergey's Manual of Systematic Bacteriology, (Eds.) Vos, P.D., Garrity, G., Jones, D., Krieg, N.R., Ludwig, W., Rainey,F.A., Schleifer, K.H., Whitman, W.B. (3): The Firmicutes, Springer, 21-127.

Mansour, N.M., H. Heine, S.M. Abdou, M.E. Shenana, M.K. Zakaria and A. El-Diwany (2014). Isolation of Enterococcus faecium NM1 13, Entercoccus faecium NM213 and Lactobacillus casei NM512 as novel probiotics with immunomodulatory properties. Microbiol Immunol. 1-11.

Maragkoudakis, P.A., G. Zoumpopoulou, C. Miaris, G. Kalantzopoulos; B. Pot and E Tsakalidou (2006). Probiotic potential of Lactobacillus species isolated from dairy products. Int. Dairy J., 16: 189-199.

Marco, M.L., S. Pavan and M. Kleerebezem (2006).Towards understanding molecular modes of probiotic action. Curr. Opin. Biotechnol., 17: 204-210.

Monteagudo-Mera, A., L. Rodriguez-Aparicio, J. Rua, H. Martinez-Blanco, N. Navasa, R.M. Garcia-Armesto and M.A. Ferrero (2012). In vitro evaluation of physiological probiotic properties of different lactic acid bacteria species of dairy and human origin. J. Funct. Foods. http:// dx. doi. org/10.1016/ j.jff. 2012.02.014.

Morrow, L.E., V. Gogineni and M.A. Malesker (2012). Probiotics in the intensive care unit. Nutr. Clin. Pract., 27 (2): 235-241.

Nacef, M., M. Chevalier, S. Chollet, D. Drider and C. Flahaut (2016). MALDI-TOF mass spectrometry for the identification of lactic acid bacteria isolated from a French cheese: The Maroilles. Int. J. Food Microbiol., 1-7.

NCCLS (2002). National Committee for Clinical Laboratory Standards, Analysis and 
Presentation of Cumulative Susceptibility Test Data: Approved Guideline. NCCLS document; M39-A.

Ouweh, G.J. and A.C. Vest (2004). Antimicrobial components from lactic acid bacteria, In Salminen, S. and Von. A. (eds). Lactic Acid Bacteria: Microbiology and Functional Aspects. $2^{\text {nd }}$ Ed., Marcel Dekker Inc., New York: 139-160.

Ouwehand, A.C., S. Salminen, S. Toekkoe, P.J. Roberts, J. Ovaska and E. Salminen (2002). Resected human colonic tissue: new model for characterizing adhesion of lactic acid bacteria. Clin. Diagn. Lab. Immunol., 9: 184186

Papamanoli, E., N. Tzanetakis, E. LitopoulouTzanetaki and P. Kotzekidou (2003). Characterization of lactic acid bacteria isolated from a Greek dry-fermented sausage in respect to their technological and probiotic properties. Meat Sci., 65 (2): 859-867.

Parasad, J., G. Harsharanjit, S. John and K. Gopal (1999). Selection and characterisation of Lactobacillus and Bifidobacterium species for use as probiotics. Int. Dairy J., 8 : 9931002.

Rivera-Espinoza, Y. and Y. Gallardo-Navarro (2010). Non-dairy probiotic products. Food Microbiol., 27 (1): 1-11.

Ruiz-Moyano, S., A. Martin, M.J. Benito, E. Aranda, R. Casquete and M.D. Cordoba (2009). Safety and functional aspects of preselected enterococci for probiotic use in Iberian dry-fermented sausages. J. Food Sci., 74: 398-404.
Sonomoto, K. and A. Yokota (2011). Lactic acid Bacteria: Antimicrobial substance. J. Appl. Bacteriol., 72: 134-142

Sridevi, N., P. Vishwe and A. Prabhune (2009). Hypocholesteremic effect of bile salt hydrolase from Lactobacillus buchneri ATCC 4005. Food Res. Int., 42: 516-520.

Tannock, G.W. (2004). A special fondness for lactobacilli.Appl. Environ. Microbiol., 70 (6): 3189-3194.

Vlkova,' E., V. Rada, P. Popela'řova', 'I. Trojanova and J. Killer (2006). Antimicrobial susceptibility of bifidobacteria isolated from gastrointestinal tract of calves. Livestock Sci., 105: 253- 259.

Wang, Y.R., Q. Chen, C.S. Hui and L.F. Qin (2013). Characterization of Staphylococcus aureus isolated from Clinical Specimens by Matrix Assisted Laser Desorption/Ionization Time-offlight Mass Spectrometry. Biomed. Environ. Sci., 26 (6): 430-436.

Xanthopoulos, V., E. Litopoulou-Tzanetaki and N. Tzanetakis (2012). Characterization of Lactobacillus isolates from infant faeces as dietary adjuncts. Food Microbiol., 17 (2): 205-215.

Yateem, A., Q. Hao and T. Enti (2008) Isolation of lactic acid bacteria with probiotic potential from camel milk.Int. J. Dairy Sci., 3: 194199.

Zacarías, M.F., A. Binetti, M. Laco, J. Reinheimer and G. Vinderola (2011). Preliminary technological and probiotic characterization of bifido-bacteria isolated from breast milk for use in dairy products. Int. Dairy J., 21: 548-555. 
انتخاب بكتيريا حامض اللاكتيك كداعمات حيوية من بعض المصادر المختلفة بواسطة الاختبارات المعملية

مها محمد نادر - عصام الدين محمود جويلي - فيكتور صموئيل بلروس - جمال الدين مصطفى محمد

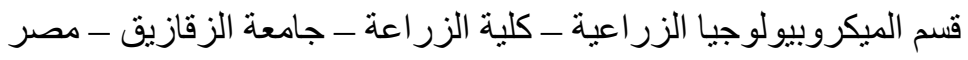

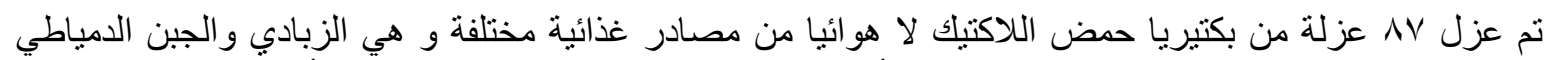

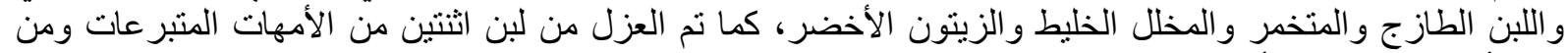

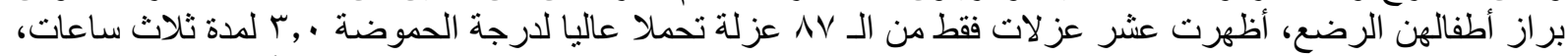

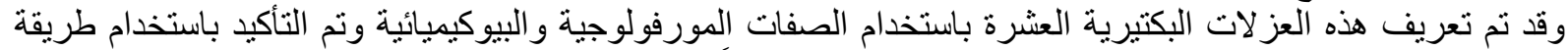
MALDI-TOF-MS أوضحت النتائج أن أكثر الأجناس نو اجداً هو جنس Lactobacillus Enterobacter faecium و وزلة واحدة Bifidobacterium bifidium تم تعريف كل العز لات الات المختبرة بكفاءة عالية

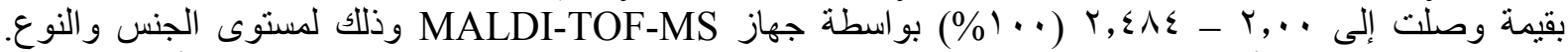

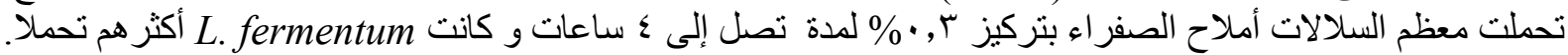

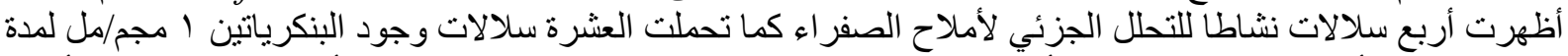

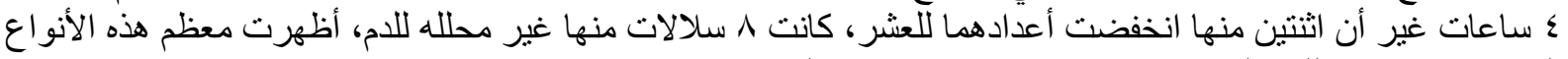

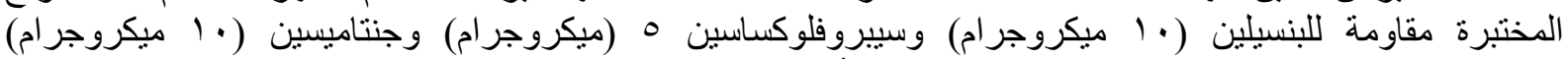

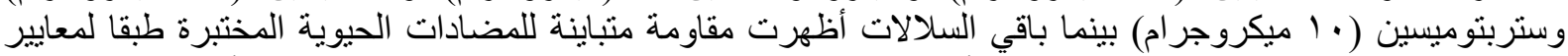

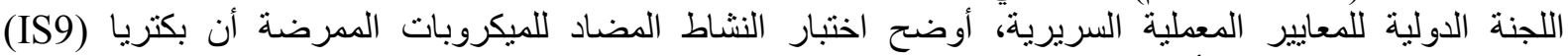

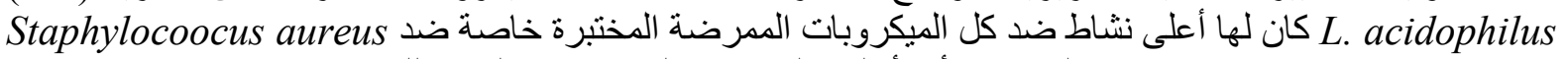
و Klebsiella pneumoniae، وعليه وجد أن أغلب السلالات المختبرة معمليا تمثلاتك صفات مرغوبة لاستخدامها كبروبيونك. 